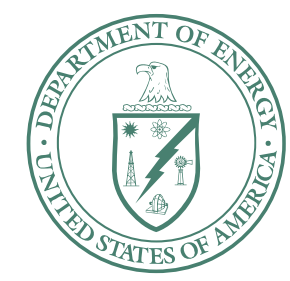

U.S. Department of Energy

Idaho Operations Office

\title{
2005 Annual Operations Report for INTEC Operable Unit 3-13, Group 1, Tank Farm Interim Action
}

July 2006 
DOE/ID-11275

Revision 1

Project Nos. 20978 and 23614

\section{Annual Operations Report for INTEC Operable Unit 3-13, Group 1, Tank Farm Interim Action}

July 2006

Prepared for the 


\begin{abstract}
This annual operations report describes the requirements followed and activities conducted to inspect, monitor, and maintain the items installed during performance of the Waste Area Group 3, Operable Unit 3-13, Group 1, Tank Farm Interim Action, at the Idaho Nuclear Technology and Engineering Center.

This report describes inspection and monitoring activities for the surface-sealed areas within the tank farm, concrete-lined ditches and culverts in and around the tank farm, the lift station, and the lined evaporation pond. These activities are intended to assure that the interim action is functioning adequately to meet the objectives stated in the Operable Unit 3-13, Record of Decision for the Group 1, Tank Farm Interim Action, (DOE/ID-10660) and as amended by the agreement to resolve dispute, which was effective in February 2003.
\end{abstract}




\section{CONTENTS}

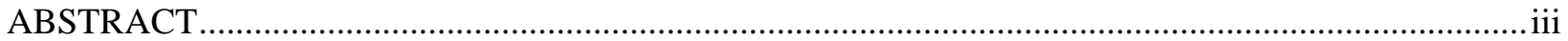

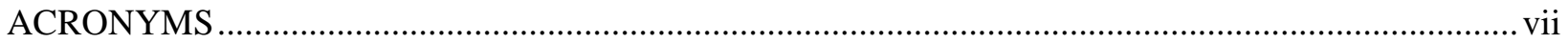

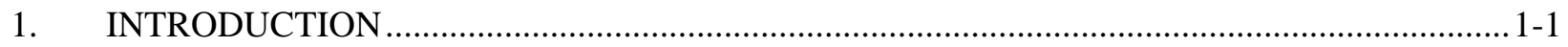

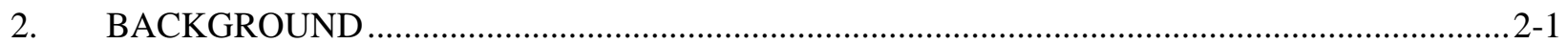

3. REQUIREMENTS FOR INSPECTIONS, RADIOLOGICAL SURVEYS, AND

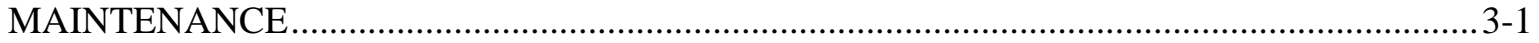

4. SUMMARY OF 2005 INSPECTIONS, MONITORING, SURVEYS, AND

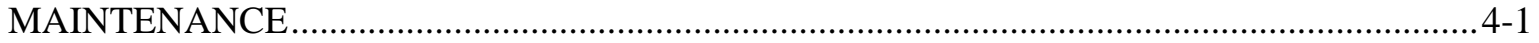

4.1 Tank Farm Surface-Sealed Areas ............................................................................... 4-2

4.2 Control Zone Asphalt-Paved Areas ............................................................................ 4-3

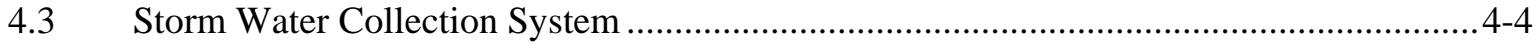

$4.4 \quad$ Olive Avenue Lift Station ..................................................................................... 4-5

4.5 Evaporation Pond Liner and Perimeter ...................................................................... 4-5

4.6 Evaporation Pond Leak Detection System ................................................................ 4-6

4.7 Evaporation Pond Sediment Inspections …............................................................ 4-7

5. AN ESTIMATE OF MAINTENANCE ACTIVITIES REQUIRED FOR THE

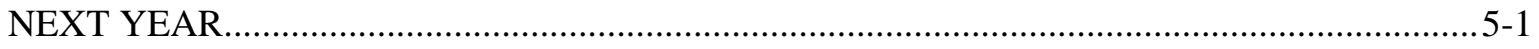

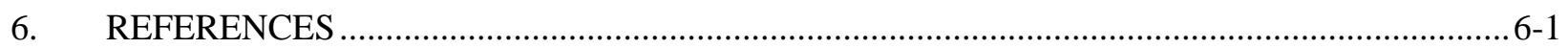

Appendix A—Analytical Results of Utility Tunnel Waters ............................................................... 1

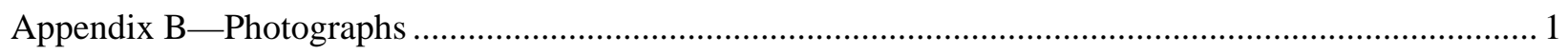

Appendix C—Lift Station CPP-1792 Lid Replacement Drawing …...................................................... 1

\section{FIGURES}

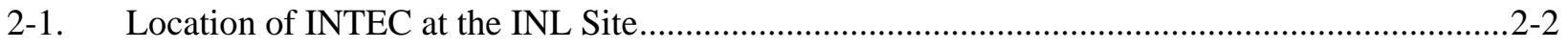

2-2. Tank Farm Interim Action components ............................................................................... 


\section{TABLES}

1-1. Operations and maintenance plan items to be included in the annual report and corresponding annual report section

3-1. Inspections, monitoring, radiological surveys, and maintenance requirements for the TFIA.

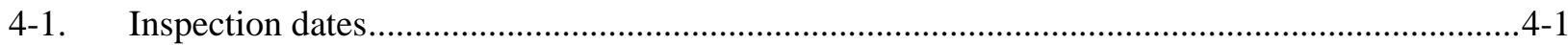

4-2. $\quad$ Summary of issues noted during tank farm surface-sealed areas inspections..............................4-2

4-3. Summary of issues noted during control zone asphalt-paved areas inspections.........................4-3

4-4. Summary of issues noted during storm water collection system inspections .............................. $4-4$

4-5. Evaporation pond leak detection monitoring data ................................................................4-8

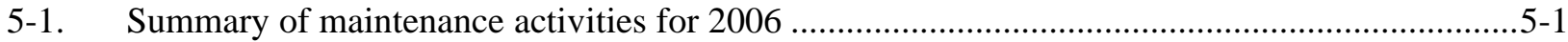




\section{ACRONYMS}

CMP corrugated metal pipe

DOE Idaho Department of Energy Idaho Operations Office

FY fiscal year

INL Idaho National Laboratory

INTEC Idaho Nuclear Technology and Engineering Center

O\&M operation and maintenance

OU operable unit

PVC polyvinyl chloride

RadCon Radiological Control

RI/FS remedial investigation/feasibility study

ROD Record of Decision

TFIA Tank Farm Interim Action

WAG waste area group 


\section{Annual Operations Report for INTEC Operable Unit 3-13, Group 1, Tank Farm Interim Action}

\section{INTRODUCTION}

The Operation and Maintenance Plan for INTEC Operable Unit 3-13, Group 1, Tank Farm Interim Action (DOE-ID 2005) contains an annual reporting requirement. This annual report for the Tank Farm Interim Action (TFIA) provides a summary of the monitoring data collected and maintenance activities performed for the time period from October 2004 through December 2005. ${ }^{\text {a }}$ Table 1-1 contains the operations and maintenance (O\&M) plan items listed for inclusion in the annual report along with the corresponding section in this annual report where they are addressed.

Table 1-1. Operations and maintenance plan items to be included in the annual report and corresponding annual report section.

\begin{tabular}{|l|l|}
\hline \multicolumn{1}{|c|}{ Operations and Maintenance Plan Items } & \multicolumn{1}{c|}{ Annual Report Section } \\
\hline A summary of the inspections performed & 4 \\
\hline A summary of pond sediment inspections & 4.7 \\
\hline A summary of maintenance activities performed & 4 \\
\hline Projected maintenance activities required for the next year & 5 \\
\hline A summary of any new source of discharge and sample results & 4.3 , Appendix A \\
\hline Evaporation pond monitoring data & 4, Table 4-5 \\
\hline
\end{tabular}

Inspections and annual reporting will continue for this interim action until the final remedy for Operable Unit (OU) 3-14 tank farm soil and groundwater is completed. Once the OU 3-14 Record of Decision (ROD) is signed, further direction will be provided.

a. The first annual operations report was produced in December 2004 for fiscal year (FY) 2004 (October 2003 through September 2004) (DOE-NE-ID 2004). After completion of this first report, the reporting period was changed from fiscal year to calendar year. This 2005 annual report includes all of 2005 plus the months of October, November, and December 2004 that spanned the gap between the end of FY-05 and calendar year 2005. Future annual reports are to cover a single 12-month period. 
1-2 


\section{BACKGROUND}

The Idaho Nuclear Technology and Engineering Center (INTEC), formerly known as the Idaho Chemical Processing Plant, is located in the south-central area of the Idaho National Laboratory (INL) Site in southeastern Idaho (see Figure 2-1). From 1952 to 1992, operations at INTEC primarily involved reprocessing spent nuclear fuel from defense projects, which entailed extracting reusable uranium from the spent fuels. Liquid waste generated from the reprocessing activities, which ceased in 1992, is stored in an underground tank farm at INTEC. Both soil and groundwater contamination resulted from these previous operations. Under the Federal Facility Agreement and Consent Order (DOE-ID 1991), the Environmental Protection Agency, Idaho Department of Environmental Quality, and Department of Energy are directing cleanup activities to reduce human health and environmental risks to acceptable levels.

Several phases of investigation have been performed at the OUs within Waste Area Group (WAG) 3. A comprehensive remedial investigation/feasibility study (RI/FS) (DOE-ID 1997a, 1997b, 1998) was conducted for OU 3-13 to determine the nature and extent of contamination and corresponding potential risks to human health and the environment under various exposure pathways and scenarios. Based on the RI/FS results, INTEC release sites were further segregated into seven groups by contaminants of concern, accessibility, or geographic proximity to allow development and analysis of remedial action alternatives. The TFIA is part of Tank Farm Soils, which was designated as Group 1 within OU 3-13. The principal threats posed by the Group 1 soils are from direct radiation exposure to workers or the public and from potential leaching and transport of soil contaminants to perched water or the Snake River Plain Aquifer. (DOE-ID 1999)

To meet the intent of the TFIA in the OU 3-13 ROD as altered in the agreement to resolve dispute (DOE 2003), the following interim action activities have been completed for the Group 1 soils:

- $\quad$ Concrete-lined storm water collection ditches were installed around the tank farm.

- $\quad$ Selected culverts around the tank farm and out to the discharge point have been replaced with larger culverts to accommodate the expected increase in storm water flow.

- $\quad$ A lift station has been constructed at the intersection of Beech Street and Olive Avenue (CPP-1792) to pump storm water to a location where it will drain freely to the discharge point.

- $\quad$ Concrete headwalls and endwalls have been constructed as necessary throughout the lined drainage system.

- A double-lined evaporation pond with a leak detection system has been constructed to collect storm water run-off from the tank farm and other INTEC areas. The pond is located east of the INTEC security fence.

- $\quad$ A fence has been constructed around the evaporation pond.

- $\quad$ Site areas CPP-28, -31, and -79, located inside the tank farm, (see Figure 2-2) were covered with a surface-sealed asphalt infiltration barrier, and a surface water drainage system was installed to drain run-off toward the storm water collection system.

- $\quad$ Asphalt coverings have been installed over selected areas in the $150-\mathrm{ft}$ control zone around the tank farm (Figure 2-2). 


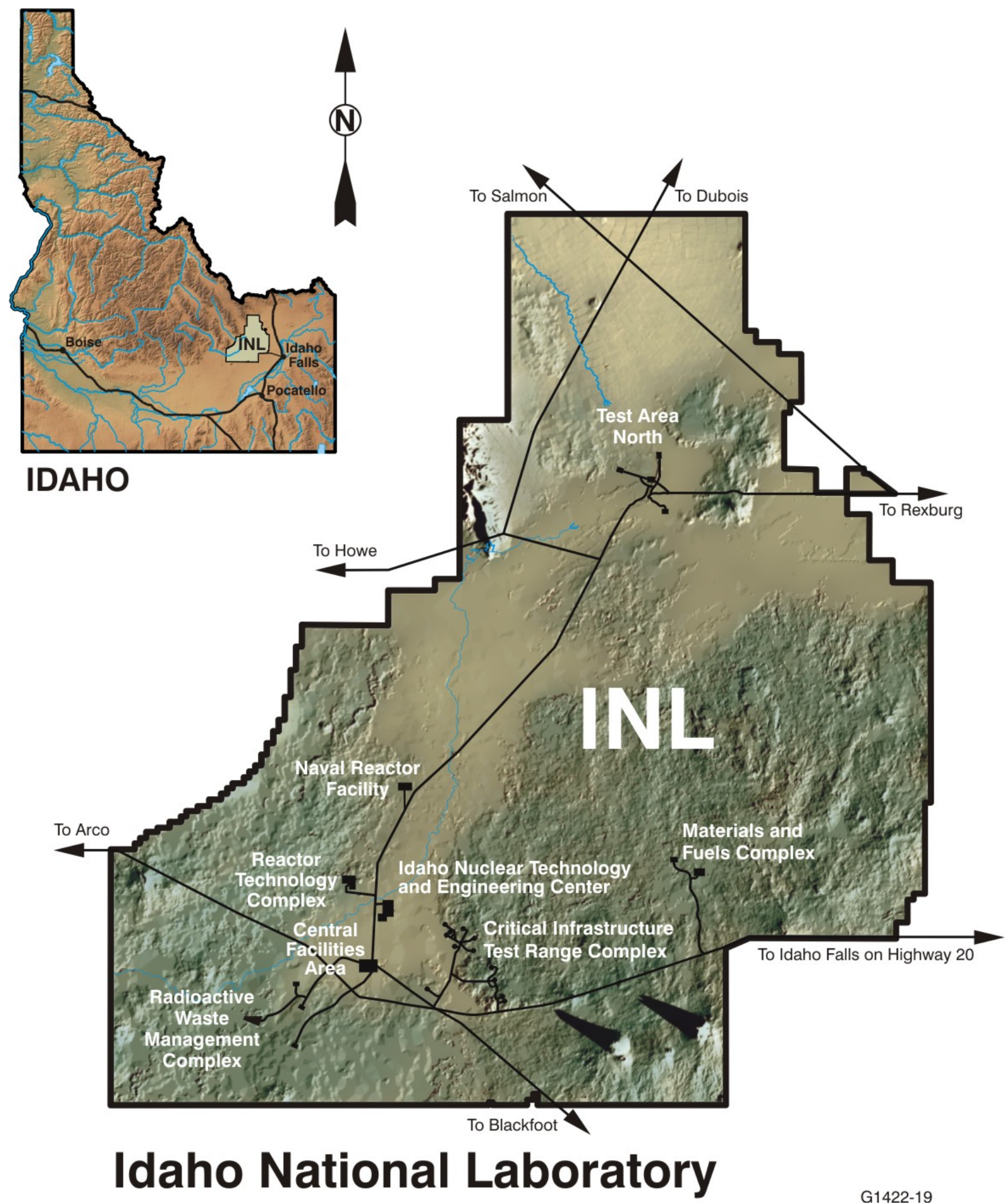

Figure 2-1. Location of INTEC at the INL Site. 


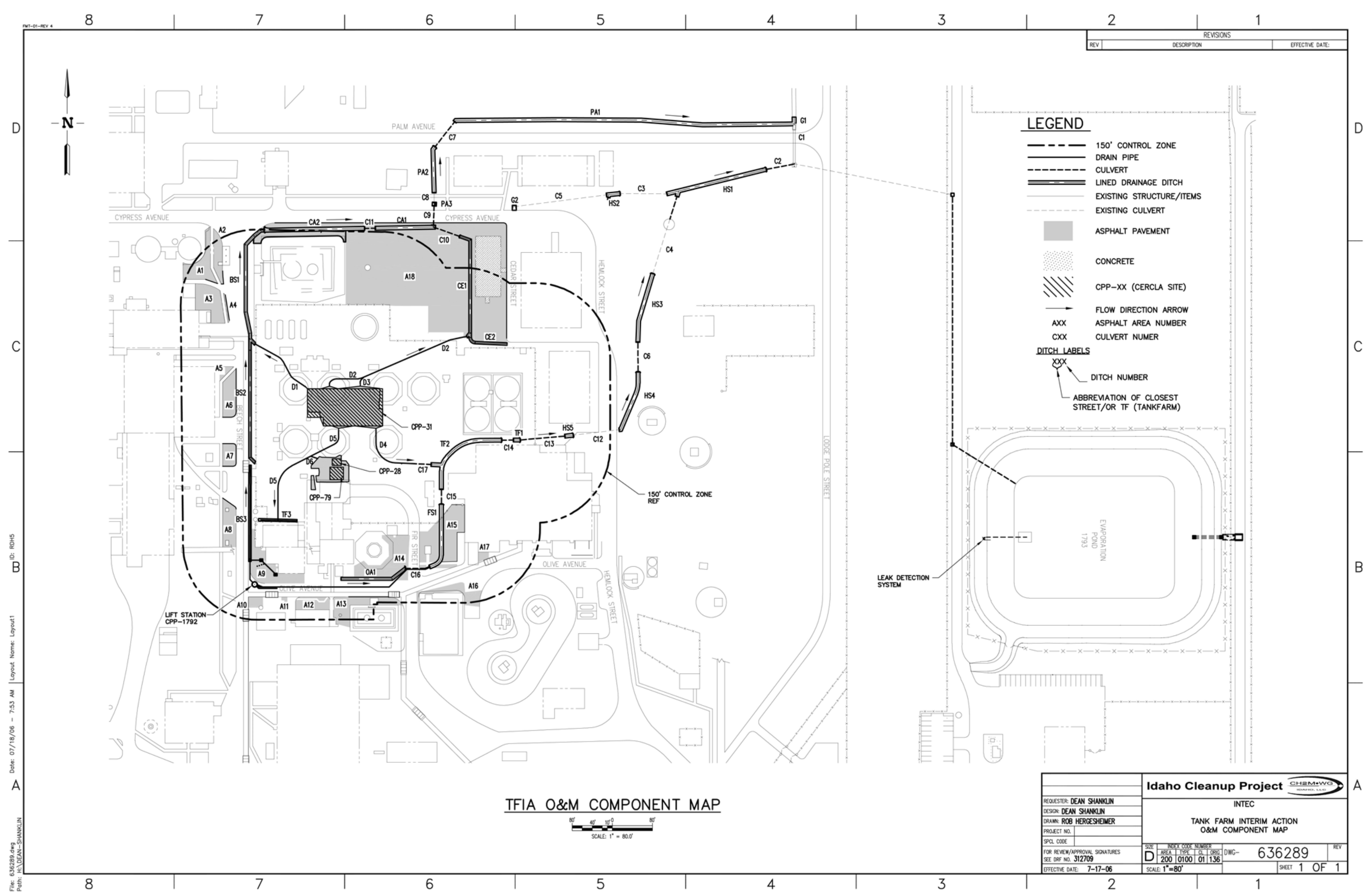

Figure 2-2. Tank Farm Interim Action components. 


\section{REQUIREMENTS FOR INSPECTIONS, RADIOLOGICAL SURVEYS, AND MAINTENANCE}

Requirements for visual inspections, radiological surveys, and maintenance were obtained from Revision 3 of the O\&M plan (DOE-ID 2005) and INTEC Radiological Control (RadCon) requirements. Table 3-1 lists each TFIA component, inspection and survey requirements, and the frequency performed during the reporting period.

Reported items that required maintenance were addressed per the requirements stated in the O\&M plan. Items located outside the tank farm were to be repaired as part of a coordinated effort with INTEC facility maintenance activities and per the specification provided in the vendor data for the equipment. Items located within the tank farm were to be repaired expeditiously to include performing temporary repairs until final repairs can be performed to route surface water run-off to the storm water collection system.

Table 3-1. Inspections, monitoring, radiological surveys, and maintenance requirements for the TFIA.

\begin{tabular}{|c|c|c|}
\hline Component & Requirement & Frequency \\
\hline $\begin{array}{l}\text { Tank farm surface- } \\
\text { sealed areas }\end{array}$ & $\begin{array}{l}\text { Inspect for cracks/potholes having } \\
\text { potential to compromise integrity of } \\
\text { infiltration barrier. Drainage piping } \\
\text { inspected for functionality. }\end{array}$ & Quarterly. \\
\hline $\begin{array}{l}\text { Control zone } \\
\text { asphalt-paved areas }\end{array}$ & $\begin{array}{l}\text { Inspect to ensure integrity, monitor } \\
\text { radiological conditions, and verify } \\
\text { drainage to the storm water collection } \\
\text { system. }\end{array}$ & Quarterly. \\
\hline $\begin{array}{l}\text { Storm water } \\
\text { collection system } \\
\text { ditches and culverts }\end{array}$ & $\begin{array}{l}\text { Inspect to ensure integrity of the } \\
\text { system, inspect to ensure drainage } \\
\text { from the tank farm and other INTEC } \\
\text { areas to the evaporation pond, and } \\
\text { monitor for radiological conditions. }\end{array}$ & Quarterly. \\
\hline $\begin{array}{l}\text { Olive Avenue lift } \\
\text { station }\end{array}$ & $\begin{array}{l}\text { Visual inspection of pumps, piping, } \\
\text { slide rails, water level hatch doors, } \\
\text { and control panel. Systems check on } \\
\text { components. }\end{array}$ & $\begin{array}{l}\text { Quarterly for visual inspections. } \\
\text { Annually and following maintenance } \\
\text { activities for systems check. }\end{array}$ \\
\hline $\begin{array}{l}\text { Evaporation pond } \\
\text { liner and perimeter }\end{array}$ & $\begin{array}{l}\text { Inspect the evaporation pond liner and } \\
\text { associated area to ensure that the liner } \\
\text { is not leaking and that the pond is } \\
\text { performing as designed. }\end{array}$ & Quarterly. \\
\hline $\begin{array}{l}\text { Evaporation pond } \\
\text { leak detection } \\
\text { system }\end{array}$ & $\begin{array}{l}\text { Inspect the leak detection system to } \\
\text { ensure it is functioning properly. } \\
\text { Systems check on components. }\end{array}$ & $\begin{array}{l}\text { Quarterly for inspections. Annually and } \\
\text { following maintenance activities for } \\
\text { systems check. }\end{array}$ \\
\hline $\begin{array}{l}\text { Evaporation pond } \\
\text { sediment } \\
\text { inspections and } \\
\text { removal }\end{array}$ & $\begin{array}{l}\text { Inspect the pond inlet and outlet for } \\
\text { sediment debris accumulation to } \\
\text { ensure that flow is not impeded. }\end{array}$ & Quarterly. \\
\hline
\end{tabular}


The schedule for the TFIA inspections is coordinated to meet the guidance provided by "Frequencies of Inspections for Hazardous Waste Storage Areas" (EA-CER-001). The document provides the following guidance concerning the scheduling of quarterly and annual inspections:

QUARTERLY - Quarterly inspections are to be conducted once every calendar quarter. The quarters are defined as January-March, April-June, July-September, and October-December. These inspections should have a minimum of 2 calendar weeks (336 hours) between consecutive inspections, i.e., conducting inspections on the last day of one quarter and then again on the next day, the first day of the next quarter, is not acceptable.

ANNUAL - Annual inspections must be conducted once every 12 consecutive months of each calendar year. These inspections should have a minimum of 11 months between consecutive inspections, i.e., conducting inspections on 12/31 and then on 1/1 is not acceptable. These inspections should have a maximum of 13 months between consecutive inspections, i.e., conducting inspections in the first month of year one and then the last month of year two is not acceptable.

When possible, the quarterly inspections are scheduled to be equally spaced during the year. However, field circumstances (e.g., coordination between projects, maintenance activities and weather conditions) will alter the actual inspection dates. For example, quarterly inspections for the October through December and the January through March timeframes may be performed earlier and later, respectively, in order to avoid adverse weather conditions (e.g., snow accumulation, high winds, extreme temperatures). 


\section{SUMMARY OF 2005 INSPECTIONS, MONITORING, SURVEYS, AND MAINTENANCE}

Inspections of the TFIA components were performed monthly from October 2004 through December 2004 (for components inside the tank farm fence) and quarterly from January 2005 through December 2005 (for all TFIA components) on the dates shown in Table 4-1. All required quarterly inspections were performed. Installed components that were inspected during this inspection period included tank farm surface-sealed areas and drainage systems; control zone asphalt-paved areas; the storm water collection system (concrete-lined drainage ditches, culverts, and the lift station); and the evaporation pond and its leak detection system. The inspections performed were scheduled inspections. No contingency inspections were ordered by the Department of Energy Idaho Operations Office (DOE Idaho). ${ }^{\mathrm{b}}$

TFIA components were also monitored for radiological conditions in accordance with INL radiological monitoring and control policies, which incorporate the requirements of 10 CFR 835.401 and 10 CFR 835.1102. This monitoring was specified based on input by INL RadCon personnel who are required to monitor areas at INTEC to (a) document radiological conditions, (b) detect changes in radiological conditions, including the gradual buildup of radioactive material, (c) verify the effectiveness of engineering and process controls in containing radioactive material and reducing radiation exposure, (d) maintain appropriate controls and restrictions to prevent the inadvertent transfer of contamination to locations outside of radiological areas, and (e) identify and control potential sources of individual exposure to radiation and/or radioactive material.

Table 4-1. Inspection dates.

\begin{tabular}{lll}
\hline \multicolumn{1}{c}{ Inspection Timeframe } & $\begin{array}{c}\text { Inside the Tank Farm Fence } \\
\text { (surface-sealed areas and } \\
\text { drainage system, lined ditches, } \\
\text { culverts) }\end{array}$ & $\begin{array}{c}\text { Outside the Tank Farm Fence } \\
\text { (control zone asphalt-paved areas, } \\
\text { water collection system, } \\
\text { evaporation pond and leak } \\
\text { detection system) }\end{array}$ \\
\hline 2004 & October 12, 2004 & No inspections \\
November 11, 2004 & No inspections \\
First quarter 2005 & December 21, 2004 & No inspections \\
Second quarter 2005 & March 29, 2005 & March 31, 2005 \\
Third quarter 2005 & June 30, 2005 & April 22 and June 28, 2005 \\
Fourth quarter 2005 & September 13, 2005 & September 6-7, 2005 \\
\hline
\end{tabular}

b. Contingency inspections are unscheduled, situation-unique inspections, ordered by DOE Idaho when it has information that indicates the site integrity has been or may be threatened. Events that might trigger contingency inspections include severe rainstorms, floods, or highly unusual events such as tornadoes and earthquakes. 


\subsection{Tank Farm Surface-Sealed Areas}

The tank farm surface-sealed areas consist of two asphalted areas: one area covers soil contamination site CPP-31 and the second area covers soil contamination sites CPP-28 and CPP-79 (see Figure 2-2). Each area uses asphalted curbing and drainage piping to collect and divert surface water run-off to the lined drainage ditches around the tank farm perimeter. Installation of the surfacesealed areas and drainage components was completed in September 2004 and inspected monthly during October, November, and December 2004, followed by quarterly inspections in 2005. All required quarterly inspections were performed. The inspections entailed an examination of the surface-sealed areas to ensure they were free of cracks and potholes that would have the potential to compromise the integrity of the surface as an infiltration barrier. In addition, the associated drainage piping was inspected for functionality to ensure a seal between the asphalt area and the discharge pipe and no visible blockage of the discharge pipe. Filter socks located at the end of each drainpipe were inspected to verify they were in place and were not obstructed by debris. Issues noted during the inspections are listed in Table 4-2.

Table 4-2. Summary of issues noted during tank farm surface-sealed areas inspections.

\begin{tabular}{|l|l|l|}
\hline $\begin{array}{c}\text { Reported } \\
\text { Date }\end{array}$ & \multicolumn{1}{|c|}{ Item } & \multicolumn{1}{c|}{ Comments and Action Taken } \\
\hline $10 / 12 / 04$ & $\begin{array}{l}\text { Probe holes in surface- } \\
\text { sealed areas CPP-28 and -79 } \\
\text { have penetrated the asphalt. }\end{array}$ & $\begin{array}{l}\text { Asphalt was repaired and surface sealed by } \\
\text { November 11, 2004. }\end{array}$ \\
\hline $10 / 12 / 04$ & $\begin{array}{l}\text { Screens }{ }^{\mathrm{a}} \text { to the inlet of the } \\
\text { corrugated metal pipe } \\
\text { (CMP) drainage pipes from } \\
\text { the surface-sealed areas } \\
\text { have not been installed. }\end{array}$ & $\begin{array}{l}\text { Screens were installed in each CMP that directs water to the } \\
\text { drainpipes by November 11, 2004. }\end{array}$ \\
\hline $3 / 29 / 05$ & $\begin{array}{l}\text { Damage to one HDPE } \\
\text { drainage pipe observed that } \\
\text { drains areas CPP-28 and } \\
\text {-79. }\end{array}$ & $\begin{array}{l}\text { Pipe was dented on the top (above water flow line) on the } \\
\text { outer ribs. The dent is less than 1/2 in. Repairs to the pipe } \\
\text { were not deemed necessary since the dent would not be } \\
\text { expected to deter the ability of the pipe to manage the } \\
\text { expected runoff. Pipe condition was monitored and noted in } \\
\text { following quarterly inspection reports. Condition remained } \\
\text { unchanged (Figure B-1 in Appendix B). }\end{array}$ \\
\hline $3 / 29 / 05$ & $\begin{array}{l}\text { Minor crack in lined ditch } \\
\text { (Figure 2-2, Ditch TF2) } \\
\text { noted. }\end{array}$ & $\begin{array}{l}\text { Crack is above water line. Does not penetrate the concrete. } \\
\text { Condition of crack is reported in following quarterly } \\
\text { inspection reports. Condition remained unchanged. }\end{array}$ \\
\hline $3 / 29 / 05$ & $\begin{array}{l}\text { Minor debris observed in } \\
\text { Ditch TF2 (gravel, paper) } \\
\text { and Ditch TF1 (plastic). } \\
\text { Ditch FS1 and Culvert C15 } \\
\text { contained cigarette butts. }\end{array}$ & $\begin{array}{l}\text { Work Request number 60000108 was written to have } \\
\text { ditches and culvert cleaned of debris. Work was completed } \\
\text { by June 30, 2005. }\end{array}$ \\
\hline
\end{tabular}


Table 4-2. (continued).

\begin{tabular}{|c|c|c|}
\hline $\begin{array}{l}\text { Reported } \\
\text { Date }\end{array}$ & Item & Comments and Action Taken \\
\hline 9/13/05 & $\begin{array}{l}\text { Polyvinyl chloride (PVC) } \\
\text { drainpipe from the top of the } \\
\text { Site CPP-79 berm has } \\
\text { separated from the asphalt } \\
\text { and is allowing surface run- } \\
\text { off to get under the surface- } \\
\text { sealed area. }\end{array}$ & $\begin{array}{l}\text { Lower part of drainpipe was removed and depression filled } \\
\text { in with concrete. Areas around inlet/outlet of remaining } \\
\text { drainpipe were sealed. Heat blankets were used to prevent } \\
\text { freezing of concrete during curing process. Area seal-coated } \\
\text { after concrete was cured. Repair method and materials } \\
\text { approved by TFIA design engineer. Agencies were informed } \\
\text { of repair plans during a WAG } 3 \text { conference call dated } \\
\text { October 13, 2005, and Agencies approved of the use of } \\
\text { concrete. Repairs were made within the 30-day time period } \\
\text { between discovery and repair as required in the O\&M } \\
\text { plan (see Figures B-2, B-3, and B-4 in Appendix B). }\end{array}$ \\
\hline 10/18/05 & $\begin{array}{l}\text { Materials stored on top of } \\
\text { the HDPE drainpipe near } \\
\text { Site CPP-79. }\end{array}$ & $\begin{array}{l}\text { All materials were removed from the area on } \\
\text { October 19, 2005. The materials caused no damage to the } \\
\text { HDPE pipe. }\end{array}$ \\
\hline \multicolumn{3}{|c|}{$\begin{array}{l}\text { a. Screens to the inlets of the CMP drainage pipe were not part of the TFIA original design but added after the final inspection, } \\
\text { which took place in September 2004, when it was observed that rabbits were entering the pipes. Screens were fabricated of } \\
\text { metal and installed at the entrance of each CMP drainage pipe in the tank farm. } \\
\text { b. HDPE = high-density polyethylene. }\end{array}$} \\
\hline
\end{tabular}

\subsection{Control Zone Asphalt-Paved Areas}

The selected asphalted areas within the 150-ft control zone (Figure 2-2) were inspected as part of the lined drainage ditch and culvert inspection. These inspections were performed quarterly on the dates listed in Table 4-1. Inspections entailed a walkdown to evaluate the integrity of the areas by looking for potential defects, damage, or deficiencies. Table 4-3 lists the issues noted during the inspections.

RadCon management has identified that these areas within the 150 - $\mathrm{ft}$ control zone are deemed to be equivalent to all other paved areas within INTEC (outside the tank farm perimeter) and did not require a periodic radiological survey.

Table 4-3. Summary of issues noted during control zone asphalt-paved areas inspections.

\begin{tabular}{ccc}
$\begin{array}{c}\text { Reported } \\
\text { Date }\end{array}$ & Item & Comments and Action Taken \\
\hline
\end{tabular}

3/31/05 Excavation activities near corner of Olive Avenue and Beech Street caused damage to asphalt.

6/28/05 Maintenance activities near the corner of Cypress Avenue and Beech Street caused damage to asphalted area.
Excavated area added to annual INTEC facility asphalt maintenance activity for repair.

Excavated area added to annual INTEC facility asphalt maintenance activity for repair. 
As reported in the FY-04 annual report, Building TB-6 (Quality Office Building) was demolished in July 2004. This building was located northwest of the tank farm and within the 150-ft control zone, and its removal left a 1,116- $\mathrm{ft}^{2}$ area open to surface water infiltration. This area was included in the INTEC facility asphalt maintenance activities and was covered with asphalt by November 2004.

\subsection{Storm Water Collection System}

The storm water collection system consists of all TFIA concrete-lined ditches and culverts as identified in Figure 2-2. Labels were created for each individual lined ditch and culvert for use in describing components within the system that have an identified maintenance item on the inspection form. The system was inspected quarterly during 2005 on the dates listed in Table 4-1. The inspection entailed walking along the entire system and visually inspecting these areas (see Figure 2-2) to ensure that (a) the ditches, culverts, and discharge areas were free of sediment and debris that could prohibit run-off to the evaporation pond and (b) the integrity of the concrete was not compromised by fully penetrating cracks.

Radiological surveys were conducted each month to monitor for radiological conditions except when snow covered the lined ditches. In addition, the radiological surveys were not performed when wet conditions precluded performing an effective radiological survey.

The lined ditches were periodically cleared of debris during the year; however, no repair and upgrade activities were performed nor were necessary on any part of the storm water collection system. Issues noted during the inspections are listed in Table 4-4.

Due to heavy precipitation in May 2005, the utility tunnel leading to the New Waste Calcining Facility began accumulating surface water run-off. This water was pumped from the utility tunnel and deposited into the nearby TFIA lined drainage ditch (south of the tank farm). This action is encouraged by the TFIA O\&M plan as a means of reducing discharges to the ground that can contribute to the transport of contaminants to the perched water. Similar waters were removed from the utility tunnel in fall 2004. These waters were subjected to a one-time sampling event to determine if they were acceptable for discharge into the TFIA lined ditches. Results indicated that all 21 radionuclides commonly encountered at INTEC were below minimum detectable activity and no other constituents of concernable levels were detected (see Appendix A for sample results). The total quantity of water discharged to the TFIA lined ditch was not measured but is estimated to be 1,000-2,000 gal.

Table 4-4. Summary of issues noted during storm water collection system inspections.

\section{Reported}

Date

Item

Comments and Action Taken

3/31/05 Ditches need to be walked and A standing work order was prepared and put in place to cleaned out, especially near culverts.

9/6/05 Cardboard box under fence in ditch near east side of tank farm. Debris in Grate G1. periodically clean out the TFIA ditches and culverts.

The standing work order to clean out TFIA ditch and culvert was implemented.

10/4/05 Grate G1 needs to be cleaned

The standing work order to clean out TFIA ditch and out. culvert was implemented. 


\subsection{Olive Avenue Lift Station}

The lift station is located in the intersection of Olive Avenue and Beech Street and is identified on Figure 2-2 as CPP-1792. The station is a 10 -ft-diameter by 15.8 -ft-deep concrete sump covered with a pair of metal hatch doors. Major components include two 5-hp submersible sewage pumps, a forced main from the sump to the ditch discharge point, and the system controls. The system was inspected routinely as part of completing a Utilities Outside Equipment Checks (Form INTEC-6998) and quarterly as part of the TFIA routine inspections. Quarterly inspections were performed on the dates listed in Table 4-1. Inspections entailed checking for high-water-level alarms, observing water level in the sump, and visually inspecting system components. During the year only one maintenance item was reported. On January 28, 2004, it was noted on the inspection form that the lift station hatch doors had been damaged (broken weld and bent surface corners) due to excessive loads on the doors. The hatch doors were barricaded off, using traffic stanchions and rope, to prevent further damage by vehicle traffic.

As stated in the FY-04 annual report, the initial plan was to add metal bracing beneath the hatch door frame and bolt it to the concrete vault section. But, upon further inspection by the project's structural engineer and original design engineer, the decision was made to replace the lift station hatch doors and concrete lid. A precast reinforced concrete lid was fabricated that incorporated a new double-leaf aluminum access cover and was designed to meet American Association of State Highway and Transportation Officials H-20 loading requirements to prevent a reoccurrence. In August 2005, the old hatch cover was replaced by the new precast cover (see drawing in Appendix $C$ for replacement details). The replacement activities required the removal of the asphalt from around the old lid, and this asphalt was not replaced due to delays in the INTEC facility annual asphalt maintenance program. This area was filled in with soil and compacted. The compacted soil is scheduled to be replaced with asphalt during the 2006 INTEC asphalt maintenance activity. This did not impact the operability of the system, which functioned normally during 2005.

The TFIA O\&M plan requires a system check be performed and documented on the electrical/mechanical components of the lift station annually and immediately following repairs and upgrade activities to assure proper equipment operation. This requirement is detailed in Revision 3 of the operations and maintenance plan (DOE-ID 2005), which was issued in April 2005. After replacement of the lift station hatch doors and concrete lid, facility maintenance performed a partial system check to ensure the lift station pumps were operational. The annual systems check was scheduled to be performed during the month of October, but, due to administrative delays, it was rescheduled to be completed by the end of November 2005. However, severe weather conditions (snow and extreme cold temperatures) and concerns of worker safety forced the rescheduling of the system check to April 2006 when conditions improved. The required system check was performed on April 9, 2006, and, during the system check, the system operated normally. The process was terminated just prior to activating the high-water alarm

due to operator concerns that a solenoid valve would be fully submerged if the system test were continued to activate the alarm and that the valve may subsequently sustain damage, resulting in a potential risk to workers. Subsequent evaluation of this valve has identified that it is specified as fully watertight. The system engineer was assigned to verify that the solenoid valve is watertight. This verification is to occur prior to the next scheduled system check.

\subsection{Evaporation Pond Liner and Perimeter}

The evaporation pond and perimeter areas were inspected quarterly on the dates listed in Table 4-1 for the following items during 2005:

- $\quad$ Liner integrity (rips/tears/environmental degradation) 
- Animal intrusion

- Vegetation growth

- $\quad$ Liner anchoring integrity/excessive tension

- $\quad$ Pond inlet and outlets free of sediment and debris

- $\quad$ Perimeter fence integrity/personal flotation devices in place

- $\quad$ No change to radiological controls.

No deficiencies, maintenance items, or radiological conditions were reported during the quarterly inspections.

\subsection{Evaporation Pond Leak Detection System}

Monitoring data were collected during each quarterly inspection (performed on the dates listed in Table 4-1) to evaluate the performance of the leak detection system. The following data were recorded:

- $\quad$ Hour meter reading (recorded the amount of time the sump pump operated)

- Water level reading (displays the level of water in leak detection sump during the inspection)

- $\quad$ Totalizer readings (cumulative gallons of water pumped from the leak detection sump and into the evaporation pond) both the day of the inspection and the following day.

The collected and calculated data are located in Table 4-5. During each quarterly inspection process, the totalizer readings did not change from Day 1 to Day 2, ${ }^{\mathrm{C}}$ resulting in a leak rate of 0 gal for 2005. A detailed explanation of the leakage rate calculation process is contained in the O\&M plan (DOE-ID 2005). The surface area of the water in the pond was estimated visually. March 2005 was the first time the entire bottom of the evaporation pond was covered by water since its completed construction in 2001. No deficiencies were reported during the inspections.

On December 26, 2005, the high-water-level alarm light was observed and recorded in the INTEC security logs. Project personnel were notified of the high-water-level alarm. Because of a work curtailment for the Christmas and New Year holidays, the personnel were notified at their personal residences. Upon project personnel's assessment of the information and consideration of this storm water collection system, secondary liner, and pump system, they identified that the high-level alarm was a condition that could be addressed on January 2, 2006. ${ }^{\mathrm{d}}$ On January 2, INTEC and project personnel assessed the leak detection control panel. They reported that the "Pump On" indicator light was lit but the pump was not operating (no discharge back into the evaporation pond) and that the water level indicator read 22.7 in. The following day, a facility electrician inspected the controls and discovered a blown fuse, which was preventing the pump from operating when the "Pump On" light was activated. The fuse was replaced and the system began operating normally. A total of 484.3 gal was then pumped from the sump and back into the pond, which equals approximately $16 \%$ of the total sump capacity. The origin of this water has been estimated to be within the seepage limits that would be expected through a primary liner

c. Leak rate calculation requires two totalizer readings to be taken on consecutive days; "Day 1" is the first day and "Day 2 ” is the second day.

d. The high-water-level alarm is not an indication of an emergency condition, only that the water in the sump has reached a predetermined level. 
and collected in the secondary system. Therefore, the quantity of water pumped from the sump is not an indication of a leak through the primary liner. The TFIA O\&M plan provides details for a required system check on the electrical/mechanical components of the leak detection system. This check is to be performed and documented at least annually to assure proper equipment operation. The annual system check was scheduled to be performed during October 2005, but snow and cold temperatures set in before work control documentation could be completed. As a result, the check was rescheduled to March 2006 to minimize worker safety issues. The required system check was performed on March 29, 2006, and, during the system check, the system operated normally. After the check, the operators noted that one of two filters (used to reduce moisture in the control panel) appeared to need replacement. A new filter has been ordered and will be installed when received.

\subsection{Evaporation Pond Sediment Inspections}

Quarterly inspections were performed on the evaporation pond inlet (northwest corner), outlets (eastern edge), and bottom for sediment and debris accumulation. No notable amounts of sediment and debris were observed in the pond inlet and outlets (thus, no sediment sampling and analysis activities took place as required by the O\&M plan). 
Table 4-5. Evaporation pond leak detection monitoring data.

\begin{tabular}{|c|c|c|c|c|c|c|c|c|c|c|c|}
\hline $\begin{array}{c}\text { Inspection } \\
\text { Date } \\
\end{array}$ & $\begin{array}{l}\text { Hour } \\
\text { Meter } \\
\text { (hr) }\end{array}$ & $\begin{array}{c}\text { Water } \\
\text { Level } \\
\text { (in.) } \\
\end{array}$ & $\begin{array}{l}\text { Totalizer } \\
\text { Day } 1^{\mathrm{a}} \\
\text { (gal) }\end{array}$ & $\begin{array}{c}\text { Totalizer } \\
\text { Day } 2^{\mathrm{a}} \\
\text { (gal) }\end{array}$ & $\begin{array}{c}\text { Totalizer } \\
\text { Difference } \\
\text { (gal) }\end{array}$ & $\begin{array}{c}\text { Estimated } \\
\text { Surface Area } \\
\text { of Water } \\
\left(\mathrm{ft}^{2}\right)\end{array}$ & $\begin{array}{c}\text { Pond } \\
\text { Bottom } \\
\text { Covered }^{\mathrm{b}} \\
(\%)\end{array}$ & $\begin{array}{l}\text { Leak } \\
\text { Rate }^{\mathrm{c}} \\
\text { (gal) } \\
\end{array}$ & $\begin{array}{c}\text { Totalizer } \\
\text { Difference } \\
\text { from } \\
\text { Previous } \\
\text { Reading } \\
\text { (gal) }\end{array}$ & $\begin{array}{l}\text { Totalizer } \\
\text { Difference } \\
\quad \text { Since } \\
\text { October } 2003^{\mathrm{d}} \\
\quad \text { (gal) }\end{array}$ & $\begin{array}{l}\text { Difference in } \\
\text { Surface Area } \\
\text { from Previous } \\
\text { Reading } \\
\quad\left(\mathrm{ft}^{2}\right)\end{array}$ \\
\hline 3/31/05 & 5.3 & 10.7 & 3,947.1 & $3,947.1$ & 0 & 76,989 & 100 & 0 & $1,785.6^{\mathrm{e}}$ & $2,558.8$ & $+44,776^{\mathrm{f}}$ \\
\hline 4/22/05 & 722.5 & 16.5 & $4,079.2$ & $4,079.2$ & 0 & 76,989 & 100 & 0 & 132.1 & $2,690.9$ & 0 \\
\hline 9/07/05 & $2,571.3$ & 17.5 & $4,079.2$ & $4,079.2$ & 0 & 25,661 & 33 & 0 & 0 & 2,690.9 & $-51,328$ \\
\hline $10 / 05 / 05$ & 3,243.1 & 17.4 & $4,079.2$ & $4,079.2$ & 0 & 38,880 & 51 & 0 & 0 & $2,690.9$ & $+13,219$ \\
\hline \multicolumn{12}{|c|}{$\begin{array}{l}\text { a. The leak rate calculation requires the inspector to record totalizer readings once per day over two consecutive days. "Day } 1 \text { ” is the first day of the inspection visit, and "Day 2” is the second. } \\
\text { b. Bottom surface area of the evaporation pond is } 76,989 \mathrm{ft}^{2} . \\
\text { c. Leak rate = (totalizer reading Day } 2-\text { totalizer reading Day } 1 \text { )/percent of pond bottom covered by water. } \\
\text { d. October } 2003 \text { is the date inspections began. } \\
\text { e. Reading September } 2004 \text { was } 2,161.5 \text { gal. } \\
\text { f. Previous reading taken on September 22, } 2004 .\end{array}$} \\
\hline
\end{tabular}




\section{AN ESTIMATE OF MAINTENANCE ACTIVITIES REQUIRED FOR THE NEXT YEAR}

All simple maintenance items reported on the inspection forms were addressed soon after they were identified (e.g., sediment and debris located in the lined drainage ditches were removed). The more complex items require planning and will be addressed by incorporating them with planned facility maintenance activities. Table 5-1 describes identified maintenance items that are planned for maintenance activities during 2006.

Table 5-1. Summary of maintenance activities for 2006.

\begin{tabular}{|c|c|c|c|c|}
\hline $\begin{array}{c}\text { Date } \\
\text { Reported } \\
\end{array}$ & Item Description & Planned Action & $\begin{array}{c}\text { Estimated } \\
\text { Cost }\end{array}$ & $\begin{array}{c}\text { Estimated } \\
\text { Completion } \\
\text { Date } \\
\end{array}$ \\
\hline 3/31/05 & $\begin{array}{l}\text { Excavation activities near } \\
\text { corner of Olive Avenue and } \\
\text { Beech Street caused } \\
\text { damage to asphalt. }\end{array}$ & $\begin{array}{l}\text { Asphalt to be } \\
\text { repaired/replaced during the } \\
\text { INTEC facility asphalt } \\
\text { maintenance activity in } 2006 \text {. }\end{array}$ & $\$ 1 \mathrm{~K}$ & July 2006 \\
\hline 6/28/05 & $\begin{array}{l}\text { Maintenance activities near } \\
\text { the corner of Cypress } \\
\text { Avenue and Beech Street } \\
\text { caused damage to asphalted } \\
\text { area. }\end{array}$ & $\begin{array}{l}\text { Area will be highly disturbed } \\
\text { during } 2006 \text { as part of a } \\
\text { reverse osmosis replacement } \\
\text { project. Will be available for } \\
\text { repair in the following year. }\end{array}$ & $\$ 2 K$ & July 2006 \\
\hline 8/31/05 & $\begin{array}{l}\text { Removed asphalt from } \\
\text { around replacement hatch } \\
\text { cover lid needs replacing. }\end{array}$ & $\begin{array}{l}\text { Asphalt to be replaced during } \\
\text { the INTEC facility asphalt } \\
\text { maintenance activity in } 2006 \text {. }\end{array}$ & $\$ 800$ & July 2006 \\
\hline
\end{tabular}




$$
\text { 5-2 }
$$




\section{REFERENCES}

10 CFR 835.401, 2002, “General requirements,” Code of Federal Regulations, Office of the Federal Register, February 2002 (as promulgated as of October 1999).

10 CFR 835.1102, 2002, “Control of areas,” Code of Federal Regulations, Office of the Federal Register, February 2002 (as promulgated as of October 1999).

DOE, 2003, United States Environmental Protection Agency, Idaho Department of Environmental Quality, United States Department of Energy, in the Matter of: the December 04, 2002, Notice of Violation and the December 20, 2002, Statement of Dispute, Agreement to Resolve Dispute, U.S. Environmental Protection Agency, Idaho Department of Environmental Quality, U.S. Department of Energy, February 21, 2003.

DOE-ID, 1991, Federal Facility Agreement and Consent Order for the Idaho National Engineering Laboratory, Administrative Docket No. 1088-06-29-120, U.S. Department of Energy Idaho Operations Office; U.S. Environmental Protection Agency, Region 10; Idaho Department of Health and Welfare, December 4, 1991.

DOE-ID, 1997a, Comprehensive RI/FS for the Idaho Chemical Processing Plant OU 3-13 at the INEEL, Part A, RI/BRA Report (Final), DOE/ID-10534, U.S. Department of Energy Idaho Operations Office, November 1997.

DOE-ID, 1997b, Comprehensive RI/FS for the Idaho Chemical Processing Plant OU 3-13 at the INEEL_Part B, FS Report (Final), DOE/ID-10572, U.S. Department of Energy Idaho Operations Office, November 1997.

DOE-ID, 1998, Comprehensive RI/FS for the Idaho Chemical Processing Plant OU 3-13 at the INEELPart B, FS Supplement Report, DOE/ID-10619, Rev. 2, U.S. Department of Energy Idaho Operations Office, October 1998.

DOE-ID, 1999, Final Record of Decision, Idaho Nuclear Technology and Engineering Center, Operable Unit 3-13, Idaho National Engineering and Environmental Laboratory, Idaho Falls, Idaho, DOE/ID-10660, Rev. 0, U.S. Department of Energy Idaho Operations Office, October 1999.

DOE-ID, 2005, Operation and Maintenance Plan for INTEC Operable Unit 3-13, Group 1, Tank Farm Interim Action, DOE/ID-10771, Rev. 3, U.S. Department of Energy Idaho Operations Office, April 2005.

DOE-NE-ID, 2004, FY-04 Annual Operations Report for INTEC Operable Unit 3-13, Group 1, Tank Farm Interim Action, DOE/NE-ID-11206, Rev. 0, U.S. Department of Energy Idaho Operations Office, December 2004.

EA-CER-001, 1999, “Frequencies of Inspections for Hazardous Waste Storage Areas,” Rev. 1, Idaho National Engineering and Environmental Laboratory, October 1999.

Form INTEC-6998, 2006, “Utilities Outside Equipment Checks,” Rev. 29, Idaho Cleanup Project, Idaho National Engineering and Environmental Laboratory, March 2006. 
6-2 


\section{Appendix A}

\section{Analytical Results of Utility Tunnel Waters}


A-2 
FINAL REPORT for CPP-659

Log Type: PLANT

Report for: RON BONE

Mailstop: $\mathbf{5 1 0 4}$

Phone Number: 6-3949

Date Received: Aug 102004 12:49

Charge \#: 100666AH1

MSA mR/hr: 0.5

Hazard Index: 1E4

PCB > 50 ppm: NO

Comments:
Log \#: 0408105

Date Approved: Aug 262004 15:07

Reviewed by: BRIAN STORMS

Signature:

Laboratory QA Review

Signature:

\begin{tabular}{|c|c|c|c|c|c|}
\hline Analysis & $\begin{array}{l}\text { Lab } \\
\text { Spl ID }\end{array}$ & $\begin{array}{l}\text { Field } \\
\text { Spl ID }\end{array}$ & Method & $\begin{array}{l}\text { Ana- } \\
\text { lyst }\end{array}$ & Results \\
\hline AG108M & 4BZ48 & 659 UTILITY TNL WTR & 53993 & WA & $<3.2956 \mathrm{E}+00 \mathrm{pCl}$ \\
\hline Ag110M & 4BZ48 & 659 UTILITY TNL WTR & 53993 & WA & $<4.571 \mathrm{E}+00 \mathrm{pC} / \mathrm{l}$ \\
\hline Alpha & 4BZ48 & 659 UTILITY TNL WTR & 23450 & WDT & $-6.51682 \mathrm{E}-01+-1.0 \mathrm{E}+00 \mathrm{pCi} / \mathrm{L}$ \\
\hline Am241 & $\begin{array}{l}\text { 4BZ48 } \\
\text { 4BZ48 }\end{array}$ & $\begin{array}{l}659 \text { UTILITY TNL WTR } \\
659 \text { UTILITY TNL WTR }\end{array}$ & $\begin{array}{l}53993 \\
13201\end{array}$ & $\begin{array}{l}\text { WA } \\
\text { WDT }\end{array}$ & $\begin{array}{l}<3.1241 \mathrm{E}+01 \mathrm{pC} / 1 \\
\text { cancelled by requester }\end{array}$ \\
\hline Beta & 4BZ48 & 659 UTILITY TNL WTR & 23450 & WDT & $6.00 \mathrm{E}+01+-5.6 \mathrm{E}+00 \mathrm{pCi} / \mathrm{L}$ \\
\hline Ce144 & 4BZ48 & 659 UTILITY TNL WTR & 53993 & WA & $<2.8684 \mathrm{E}+01 \mathrm{pC} / \mathrm{l}$ \\
\hline Co58 & 4BZ48 & 659 UTILITY TNL WTR & 53993 & WA & $<3.2194 \mathrm{E}+00 \mathrm{pC} / \mathrm{l}$ \\
\hline Co60 & 4BZ48 & 659 UTILITY TNL WTR & 53993 & WA & $<3.7383 \mathrm{E}+00 \mathrm{pC} / \mathrm{l}$ \\
\hline Cs134 & 4BZ48 & 659 UTILITY TNL WTR & 53993 & WA & $<3.6253 \mathrm{E}+00 \mathrm{pCl}$ \\
\hline Cs137 & 4BZ48 & 659 UTILITY TNL WTR & 53993 & WA & $<4.2295 \mathrm{E}+00 \mathrm{pCl}$ \\
\hline Eu152 & 4BZ48 & 659 UTILITY TNL WTR & 53993 & WA & $<1.1119 \mathrm{E}+01 \mathrm{pC} / \mathrm{l}$ \\
\hline Eu154 & 4BZ48 & 659 UTILITY TNL WTR & 53993 & WA & $<9.9523 \mathrm{E}+00 \mathrm{pCl}$ \\
\hline Eu155 & 4BZ48 & 659 UTILITY TNL WTR & 53993 & WA & $<1.6152 \mathrm{E}+01 \mathrm{pC} / \mathrm{l}$ \\
\hline Mn54 & 4BZ48 & 659 UTILITY TNL WTR & 53993 & WA & $<3.3665 \mathrm{E}+00 \mathrm{pCl}$ \\
\hline NB94 & 4BZ48 & 659 UTILITY TNL WTR & 53993 & WA & $<3.3802 \mathrm{E}+00 \mathrm{pCl}$ \\
\hline Nb95 & 4BZ48 & 659 UTILITY TNL WTR & 53993 & WA & $<3.2506 \mathrm{E}+00 \mathrm{pCl}$ \\
\hline Ra226 & 4BZ48 & 659 UTILITY TNL WTR & 53993 & WA & $<9.4941 \mathrm{E}+01 \mathrm{pCl}$ \\
\hline Ru103 & 4BZ48 & 659 UTILITY TNL WTR & 53993 & WA & $<3.461 \mathrm{E}+00 \mathrm{pC} / \mathrm{l}$ \\
\hline Ru106 & 4BZ48 & 659 UTILITY TNL WTR & 53993 & WA & $<3.2467 \mathrm{E}+01 \mathrm{pC} / \mathrm{l}$ \\
\hline $\mathrm{Sb} 125$ & 4BZ48 & 659 UTILITY TNL WTR & 53993 & WA & $<9.9616 \mathrm{E}+00 \mathrm{pCl}$ \\
\hline U235 & 4BZ48 & 659 UTILITY TNL WTR & 53993 & WA & $<5.7668 \mathrm{E}+00 \mathrm{pCl}$ \\
\hline Zn65 & 4BZ48 & 659 UTILITY TNL WTR & 53993 & WA & $<7.5684 \mathrm{E}+00 \mathrm{pC} / \mathrm{l}$ \\
\hline Zr95 & 4BZ48 & 659 UTILITY TNL WTR & 53993 & WA & $<5.7482 \mathrm{E}+00 \mathrm{pCl}$ \\
\hline
\end{tabular}

End of Report. Total: $\mathbf{2 4}$ 


\section{INTERIM REPORT for CPP 659 UTILITY}

Log Type: PLANT

$\log \#: 0409081$

Report for: SEE COMMENTS

Mailstop: $\mathbf{5 1 0 4}$

Phone Number: 6-1043

Date Received: Sep 92004 09:09

Charge \#: 100666AH1

MSA mR/hr: COLD

Hazard Index: <1E4

$\mathrm{PCB}>50 \mathrm{ppm}$ : NO

Comments:

Final reports to: Ron Bone and Bob Rogers at M/S 5104. Per Ron Bone these samples are not RCRA Protocol.

\begin{tabular}{|c|c|c|c|c|c|}
\hline Analysis & $\begin{array}{l}\text { Lab } \\
\text { Spl ID }\end{array}$ & $\begin{array}{l}\text { Field } \\
\text { Spl ID } \\
\end{array}$ & Method & $\begin{array}{l}\text { Ana- } \\
\text { lyst }\end{array}$ & Results \\
\hline Arsenic & 4CF18 & CPP 659 UTILITY WTR & 42900 & DSL & Not Detected: IDL= 2.941176 ug/L \\
\hline Barium & 4CF18 & CPP 659 UTILITY WTR & 42900 & DSL & $2.29412 \mathrm{E}+01 \mathrm{ug} / \mathrm{L}$ \\
\hline Cadmium & 4CF18 & CPP 659 UTILITY WTR & 42900 & DSL & Not Detected: IDL $=0.3529412 \mathrm{ug} / \mathrm{L}$ \\
\hline Chromium & 4CF18 & CPP 659 UTILITY WTR & 42900 & DSL & $2.0 \mathrm{E}+00 \mathrm{ug} / \mathrm{L}$ \\
\hline Lead & 4CF18 & CPP 659 UTILITY WTR & 42900 & DSL & Not Detected: IDL= $7.411765 \mathrm{ug} / \mathrm{L}$ \\
\hline Mercury & 4CF18 & CPP 659 UTILITY WTR & 22809 & SDN & Not Detected: IDL $=0.1666667 \mathrm{ug} / \mathrm{L}$ \\
\hline $\mathrm{pH}$ & 4CF18 & CPP 659 UTILITY WTR & 87016 & PJK & $9.882 \mathrm{E}+00+-3.8 \mathrm{E}-02 \mathrm{PH}$ \\
\hline Selenium & 4CF18 & CPP 659 UTILITY WTR & 42900 & DSL & Not Detected: IDL= 4.117647 ug/L \\
\hline SEMIVOL PREP & 4CF18 & CPP 659 UTILITY WTR & $9500 \mathrm{~s}$ & & \\
\hline Silver & $4 \mathrm{CF} 18$ & CPP 659 UTILITY WTR & 42900 & DSL & Not Detected: IDL $=4.352941$ ug $/ \mathrm{L}$ \\
\hline $\mathrm{SpGr}$ & $4 \mathrm{CF} 18$ & CPP 659 UTILITY WTR & 87980 & PJK & 1.003E+00 +- 1.0E-02@ 25/4 \\
\hline SVOA (TOTAL) & $4 \mathrm{CF} 18$ & CPP 659 UTILITY WTR & 9270 & & \\
\hline TOC & $4 \mathrm{CF} 18$ & CPP 659 UTILITY WTR & 18060 & PJK & 1.16E+01 +- $1.1 \mathrm{E}+00 \mathrm{ug} / \mathrm{ml}$ \\
\hline Total CarboN & $4 \mathrm{CF} 18$ & CPP 659 UTILITY WTR & 18060 & PJK & NOT RUN \\
\hline Total Sr & 4CF18 & CPP 659 UTILITY WTR & 13381 & PAT & No strontium detected. < rgt. blk. \\
\hline TSS & $4 \mathrm{CF} 18$ & CPP 659 UTILITY WTR & 17975 & PJK & $156.25 \mathrm{mg} / \mathrm{L}$ \\
\hline VOA (TOTAL) & 4CF18 & CPP 659 UTILITY WTR & 9260 & & \\
\hline
\end{tabular}

End of Report. Total: 14 
Appendix B

Photographs 
B-2 


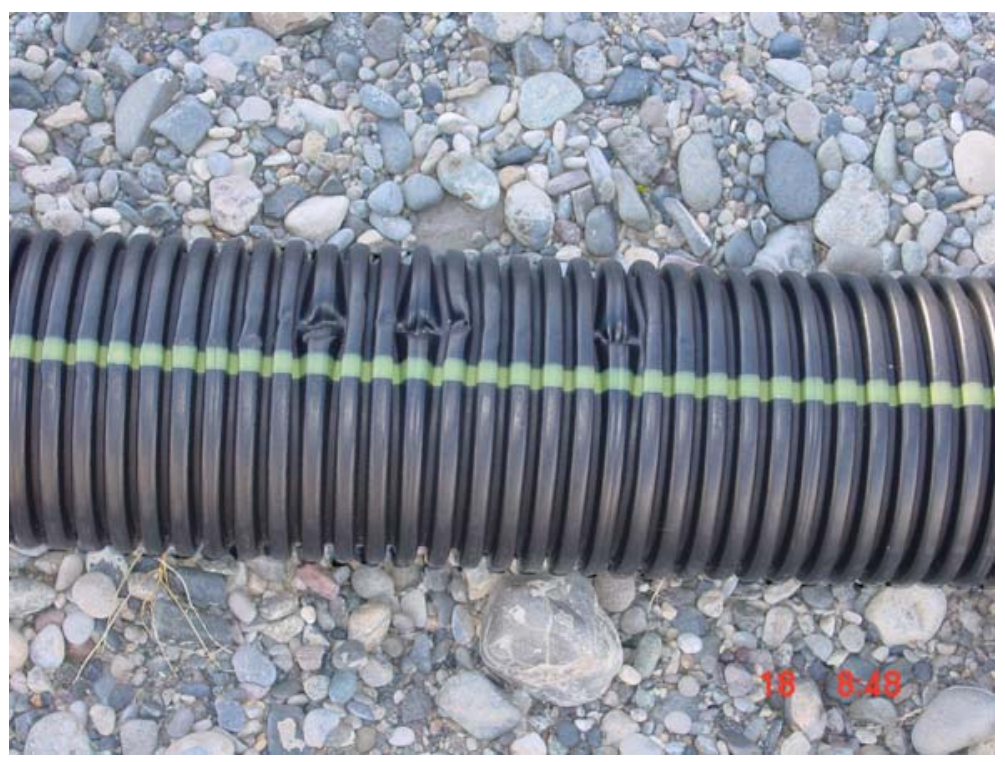

Figure B-1. Damage to high-density polyethylene pipe that drains Sites CPP-28 and -79.

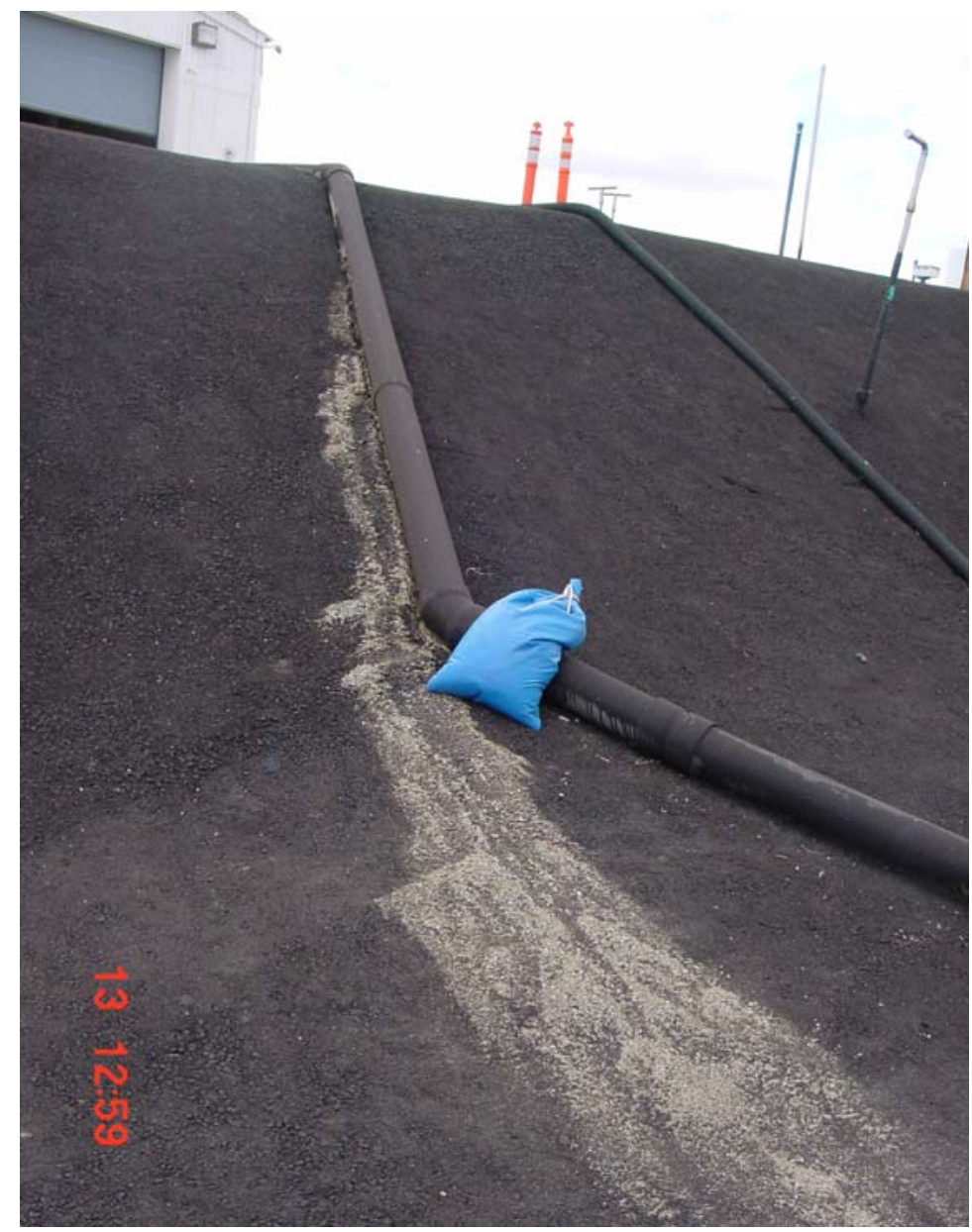

Figure B-2. Drain line over Site CPP-79 separated from asphalt and allowed water to get under asphalt layer. 


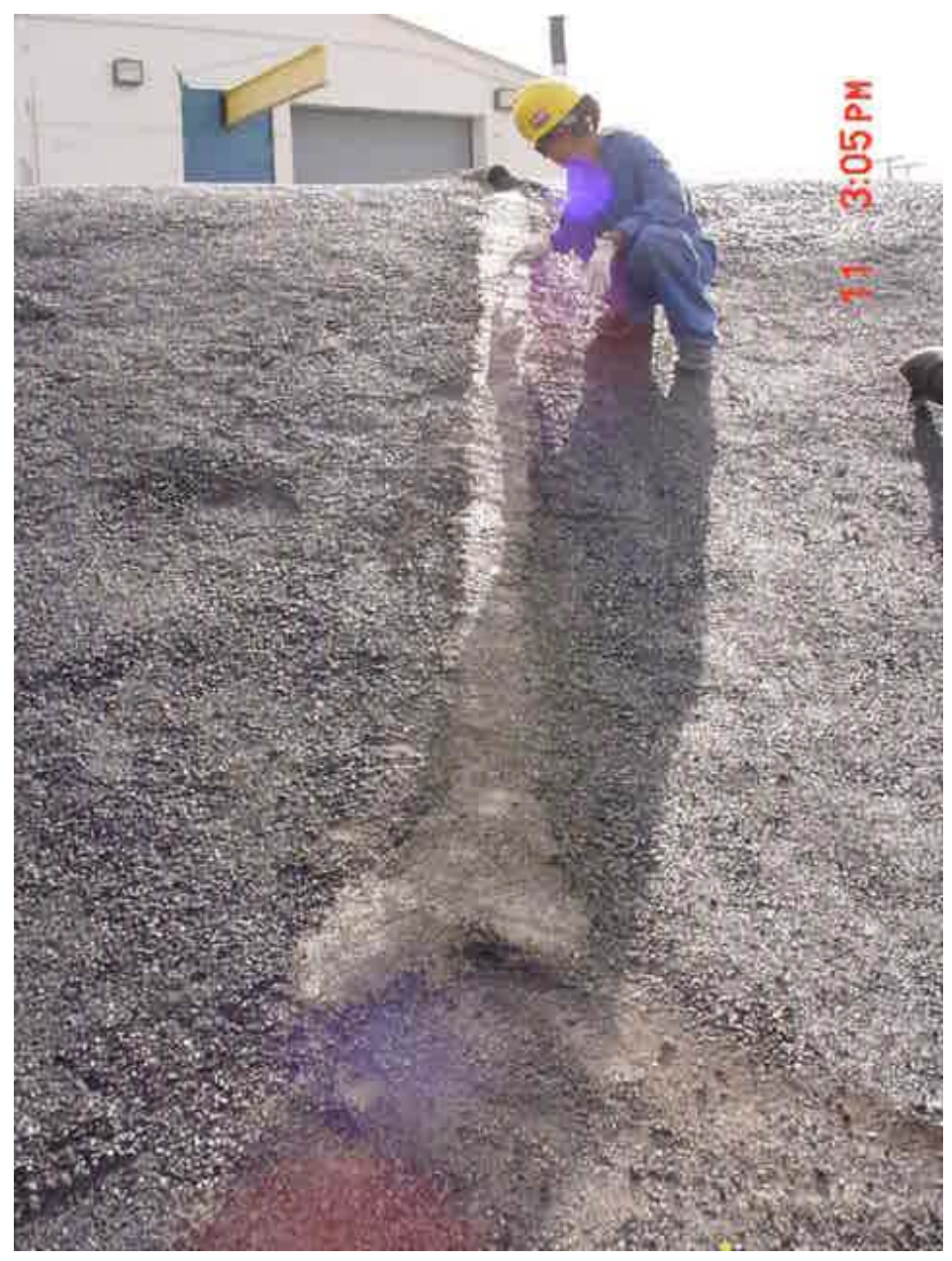

Figure B-3. Lower part of drain line over Site CPP-79 removed and depression filled in with concrete.

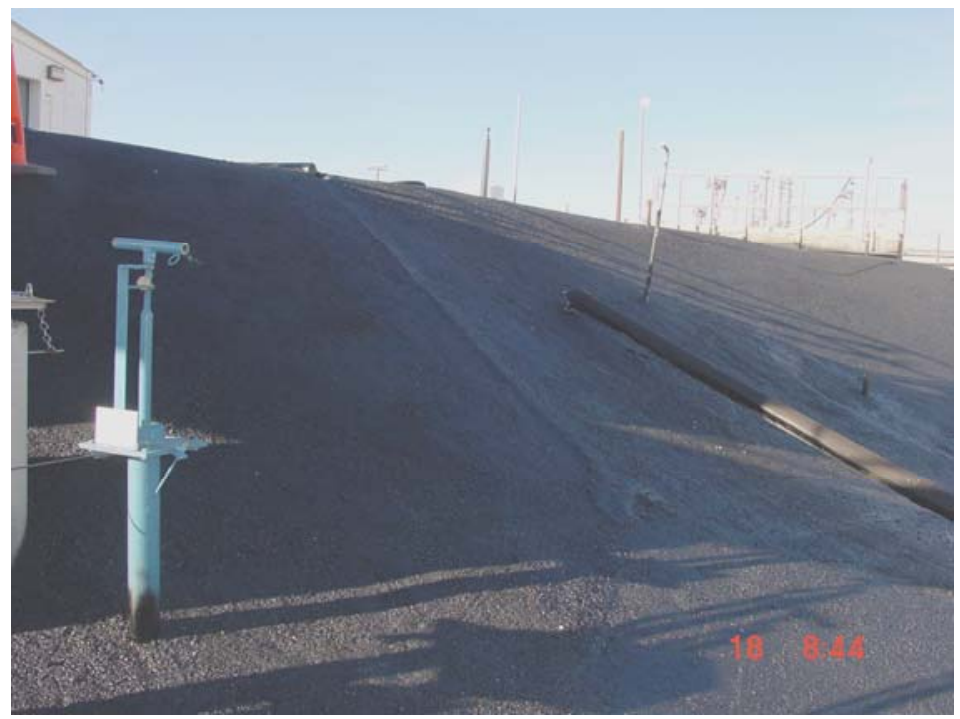

Figure B-4. Showing drain line over Site CPP-79 removed, depression filled in with concrete, and area sealed with seal coat. 
Appendix C

\section{Lift Station CPP-1792 Lid Replacement Drawing}




$$
\text { C-2 }
$$




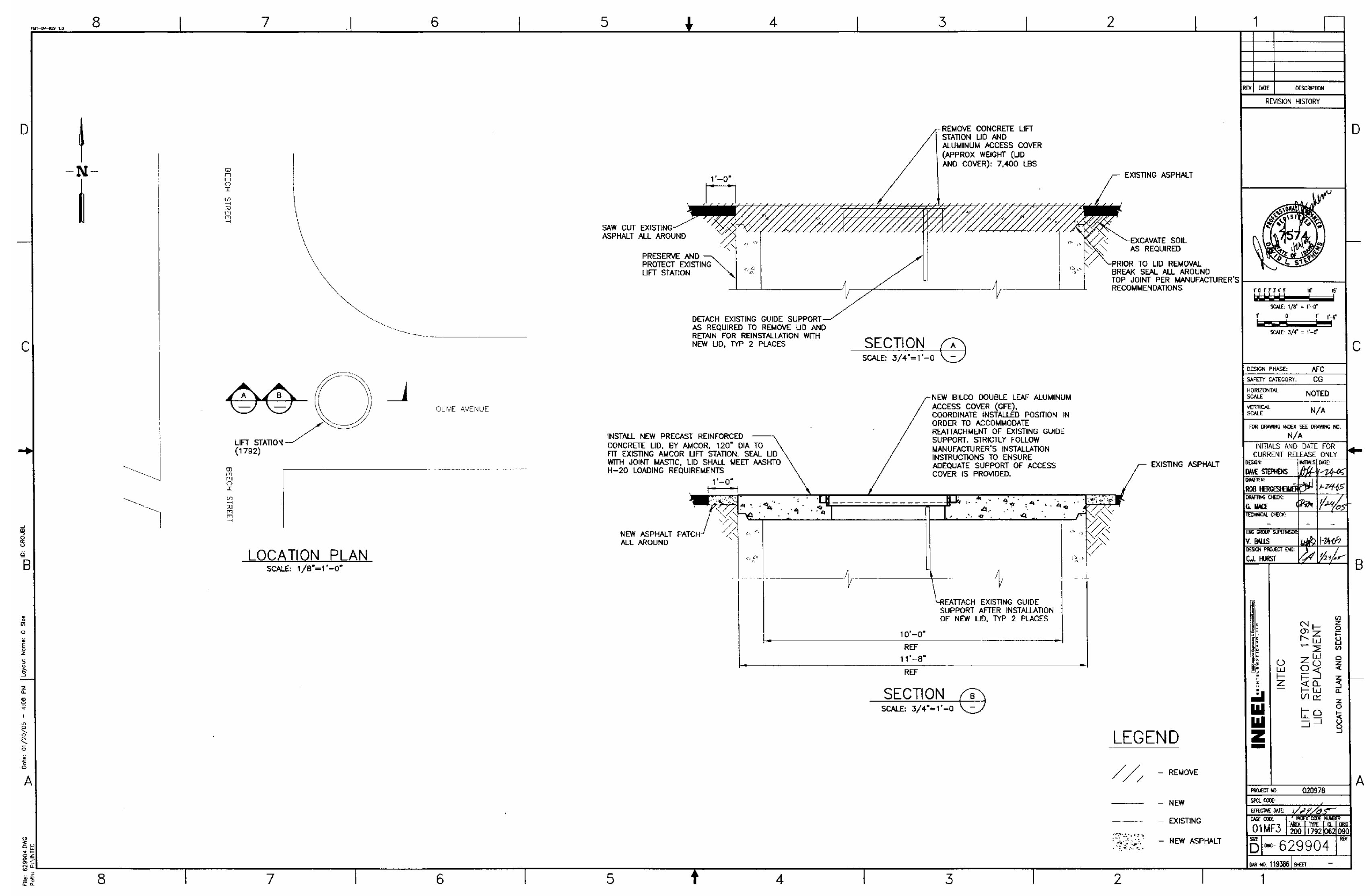

